\title{
Primary resistance to dapsone among untreated lepromatous patients in Bamako and Chingleput*
}

\begin{abstract}
Subcommittee on Clinical Trials of the Chemotherapy of Leprosy (THELEP) Scientific Working Group of the UNDP/World Bank/ WHO Special Programme for Research and Training in Tropical Diseases
\end{abstract}

Summary More than one-third of the patients with lepromatous leprosy, presumed previously untreated, who have thus far been admitted into the THELEP controlled clinical trials in Bamako and Chingleput, have been found to harbour dapsone-resistant Mycobacterium leprae.

Members of the THELEP Clinical Trials Subcommittee are:

Dr G A Ellard, National Institute for Medical Research, London, UK,

Dr C A P Ferracci, Institut Marchoux, Bamako, Mali,

Dr C G S Iyer, Central Leprosy Teaching and Research Institute, Chingleput, South India,

Dr Kyaw Lwin, Ministry of Health, Rangoon, Burma,

Dr D L Leiker, Royal Tropical Institute, Amsterdam, the Netherlands,

Dr L Levy, Hebrew University-Hadassah Medical School, Jerusalem, Israel,

Dr N E Morrison, The Johns Hopkins University School of Hygiene and Public Health, Baltimore, Maryland, USA,

Dr S K Noordeen, World Health Organization, Geneva, Switzerland,

Dr S R Pattyn, Prince Leopold Institute for Tropical Medicine, Antwerp, Belgium,

Dr J M H Pearson, Dhoolpet Leprosy Research Centre, Hyderabad, India,

Dr R J W Rees, National Institute for Medical Research, London, UK,

Dr H Sansarricq, World Health Organization, Geneva, Switzerland,

Dr P S Seshadri, Central Leprosy Teaching and Research Institute, Chingleput, South India,

Dr J K Seydel, Borstel Research Institute, Borstel, Federal Republic of Germany, Dr C C Shepard, Centers for Disease Control, Atlanta, Georgia, USA, Dr M F R Waters, Hospital for Tropical Diseases, London, UK.

Also participating in this study were R D Lancaster, M J Colston and G R F

* This report was prepared by Dr L Levy. 
Hilson, Department of Medical Microbiology, St George's Hospital Medical School, London, UK.

\section{Introduction}

Until 10 years ago, virtually all strains of Mycobacterium leprae isolated from patients with previously untreated multibacillary* leprosy by inoculation of mice were inhibited from multiplying by administering dapsone to the mice in a concentration of $0.0001 \mathrm{~g}$ per $100 \mathrm{~g}$ mouse diet. ${ }^{2,5,9}$ Strains of M. leprae capable of multiplying in mice administered this or a higher concentration of dapsone were defined as resistant. Strains that multiply in mice administered $0.0001 \mathrm{~g}$ dapsone per $100 \mathrm{~g}$ diet, but are inhibited by dapsone administered in a concentration of $0.001 \mathrm{~g}$ per $100 \mathrm{~g}$ diet are said to exhibit a low degree of resistance; strains that multiply in mice administered $0.001 \mathrm{~g}$ dapsone per $100 \mathrm{~g}$ diet but not in mice administered dapsone in a concentration of $0.01 \mathrm{~g}$ per $100 \mathrm{~g}$ exhibit an intermediate degree of resistance, whereas strains of $M$. leprae that multiply even in mice administered $0.01 \mathrm{~g}$ dapsone per $100 \mathrm{~g}$ diet exhibit a high degree of resistance.

The isolation of a resistant strain of $M$. leprae from a patient with multibacillary leprosy who has not received prior treatment indicates primary resistance to dapsone, i.e. the patient was infected ab initio with dapsone-resistant organisms. Primary resistance to dapsone may also occur in patients with paucibacillary leprosy; however, resistance of the $M$. leprae to dapsone cannot be demonstrated by inoculation of mice, because too few organisms can be recovered from the skin-biopsy specimens of paucibacillary patients. Secondary resistance to dapsone is now a widespread phenomenon. ${ }^{3}$ As the frequency of relapse with secondary dapsone resistance increases, so must the likelihood of transmission of dapsone-resistant $M$. leprae, with primary resistance as a consequence.

Recognizing that dapsone resistance represents a major threat to leprosy control efforts that depend so heavily on the efficacy of dapsone, the Scientific Working Group on the Chemotherapy of Leprosy (THELEP) of the UNDP/ World Bank/WHO Special Programme for Research and Training in Tropical Diseases undertook to support surveys for primary resistance to dapsone in various parts of the world. The results of two surveys - one in Ethiopia ${ }^{4}$ and one in the Philippines ${ }^{1}$ - have been published. In addition, susceptibility to dapsone was measured routinely of the $M$. leprae isolated from patients with previously untreated multibacillary leprosy recruited into THELEP-sponsored controlled

* Multibacillary leprosy includes lepromatous (L) and borderline (B) leprosy in the Madrid classification, ${ }^{13}$ and LL, BL and BB leprosy in the Ridley-Jopling classification. ${ }^{7}$ Paucibacillary leprosy includes indeterminate (I) and tuberculoid (T) leprosy in the Madrid classification, and I, $\mathrm{TT}$ and BT in the classification of Ridley and Jopling. 
trials of chemotherapy in Bamako, Mali and Chingleput, South India; ${ }^{11}$ the results of these measurements have provided estimates of the prevalence of primary dapsone resistance in these 2 areas.

\section{Materials and methods}

With their consent, patients with LL, LI or BL leprosy who denied prior treatment, and in whose urine no dapsone could be detected, were admitted into the controlled clinical trials at Bamako and Chingleput. As described in the accompanying paper, ${ }^{11}$ two skin lesions were biopsied, and portions of each biopsy specimen were immediately placed in a vacuum flask filled with ice and sent by air to London. In the Department of Medical Microbiology, St George's Hospital Medical School, the specimens were homogenized, and the M. leprae recovered and counted. ${ }^{5}$ The organisms recovered from the specimen providing the larger number were diluted so as to provide an inoculum of $10^{4} \mathrm{M}$. leprae per foot-pad, and 27 locally bred female CD-1 mice were inoculated each in the right hind foot-pad. Beginning on the day of inoculation, one group of 8 mice was fed ordinary mouse diet, whereas other groups of 5-7 mice were fed diet into which had been incorporated dapsone in a concentration of $0 \cdot 0001,0.001$ or $0 \cdot 01 \mathrm{~g}$ per $100 \mathrm{~g}$ diet.

Six months later, several mice from the untreated group were sacrificed, and harvests of $M$. leprae were performed from the right hind foot-pads. If at least $5 \times 10^{5}$ organisms were harvested from 1 mouse, harvests were performed from the right hind foot-pads of the remaining untreated mice, and from the foot-pads of the mice administered dapsone in the lowest concentration. If $M$. leprae were found to have multiplied in the latter mice, harvests were performed also from mice of the groups administered dapsone in higher concentrations. If, on the other hand, the number of organisms harvested from the untreated mice was less than $5 \times 10^{5}$ per foot-pad, dapsone administration was continued for an additional 3 months, at which time additional untreated mice were sacrificed and harvests of $M$. leprae performed. At this time also, additional harvests were performed if at least $5 \times 10^{5}$ organisms were harvested from at least 1 mouse. If fewer than $5 \times 10^{5}$ organisms per foot-pad were harvested from the untreated mice, treatment was continued for an additional 3 months, at which time $M$. leprae were harvested from all remaining untreated mice, from the mice administered the lowest concentration of dapsone, and depending on the results of these latter harvests, from mice administered higher concentrations of dapsone.

\section{Results}

The results of mouse foot-pad inoculation with $M$. leprae recovered from the pretreatment specimens of 2 patients are presented in Table 1 as examples of the 
Table 1. Data exemplifying those encountered in study

\begin{tabular}{|c|c|c|c|c|c|}
\hline $\begin{array}{l}\text { Treatment } \\
\text { centre }\end{array}$ & $\begin{array}{c}\text { Patient } \\
\text { no. }\end{array}$ & $\begin{array}{l}\text { No. M. leprae } \\
\text { inoculated } \\
\quad\left(\times 10^{4}\right)\end{array}$ & $\begin{array}{c}\text { Time of } \\
\text { harvest } \\
\text { (days) }\end{array}$ & $\begin{array}{c}\text { Dapsone } \\
\text { concentration } \\
\left(\mathrm{g}^{\mathrm{o}} \mathrm{o}\right)\end{array}$ & $\begin{array}{l}\text { No. M. leprae recovered } \\
\qquad\left(\times 10^{5}\right)\end{array}$ \\
\hline Chingleput & 002 & $1 \cdot 0$ & $\begin{array}{l}183 \\
268 \\
359\end{array}$ & $\begin{array}{l}0 \\
0 \\
0 \\
0 \cdot 0001\end{array}$ & $\begin{array}{l}<0 \cdot 1,<0 \cdot 1 \\
0 \cdot 72,1 \cdot 4,2 \cdot 9 \\
0 \cdot 20,2 \cdot 5,6 \cdot 8 \\
<0 \cdot 1,<0 \cdot 1,<0 \cdot 1 \\
<0 \cdot 1,<0 \cdot 1,<0 \cdot 1\end{array}$ \\
\hline Chingleput & 028 & $1 \cdot 0$ & $\begin{array}{l}189 \\
282\end{array}$ & $\begin{array}{l}0 \\
0 \\
0 \cdot 0001 \\
0 \cdot 001\end{array}$ & $\begin{array}{l}0 \cdot 18,0 \cdot 66,0 \cdot 66 \\
1 \cdot 2,2 \cdot 6 \\
0 \cdot 52,0 \cdot 80,2 \cdot 7,4 \cdot 0,6 \cdot 9 \\
<0 \cdot 1,<0 \cdot 1,<0 \cdot 1,<0 \cdot 1, \\
<0 \cdot 1,<0 \cdot 1,<0 \cdot 1\end{array}$ \\
\hline
\end{tabular}

data analysed for this study. Shown first are the data from Chingleput patient No. 002, whose organisms are susceptible to dapsone. Considering only those harvests performed 268 and 359 days after inoculation, M. leprae are noted to have multiplied in 5 of the 6 untreated mice harvested (the criterion of multiplication in a foot-pad is an increase of at least 5 -fold, i.e. to $5 \times 10^{4}$ organisms per foot-pad). On the other hand, no evidence of multiplication was found in any of the 6 mice administered dapsone in a concentration of $0.0001 \mathrm{~g}$ per $100 \mathrm{~g}$ diet.

The results obtained from Chingleput patient No. 028 indicate resistance at the lowest dapsone concentration. $M$. leprae had multiplied in the 2 control mice harvested after 282 days. At this time $M$. leprae were found also to have multiplied in all of 5 mice treated with dapsone at the lowest concentration, and in none of 7 mice treated with dapsone at the concentration of $0.001 \mathrm{~g}$ per $100 \mathrm{~g}$ mouse diet.

Table 2. Results of study

\begin{tabular}{lcc}
\hline & Bamako & Chingleput \\
\hline Not tested & 5 & 11 \\
Fully susceptible & 26 & 35 \\
Resistant (g\% DDS) & & \\
0.0001 & 10 & 16 \\
0.001 & 3 & 5 \\
0.01 & 1 & 0 \\
$\%$ resistant & $35 \cdot 0$ & $37 \cdot 5$ \\
\hline
\end{tabular}


The results of this study, summarized in Table 2, show that in a number of instances, representing $11 \%$ of the patients in Bamako and $16 \%$ of those in Chingleput, the susceptibility to dapsone could not be measured. The M. leprae recovered from 10 pretreatment biopsy specimens ( 3 from Bamako, 7 from Chingleput) failed to multiply in untreated mice. In 6 instances ( 2 from Bamako, 4 from Chingleput), $M$. leprae multiplied in some of the untreated mice, and in none of the mice to which dapsone had been administered; however, the proportions of treated and untreated mice in which multiplication occurred did not differ significantly, when compared by the exact probability calculation.

The $M$. leprae isolated from 35 and $37.5 \%$ of the patients in Bamako and Chingleput, respectively, multiplied both in untreated mice and in mice administered dapsone in a concentration of $0.0001 \mathrm{~g}$ per $100 \mathrm{~g}$ mouse diet, and more than one-fourth of these strains multiplied in mice administered dapsone in a higher concentration. However, only 1 patient was found to harbour M. leprae capable of multiplication in mice administered dapsone in the highest concentration.

\section{Discussion}

The requirement for testing the susceptibility to dapsone of the $M$. leprae isolated from the pretreatment biopsy specimens of all the patients admitted to the THELEP controlled clinical trials in Bamako and Chingleput was included in the THELEP Standard Protocol for Chemotherapy Trials in Lepromatous Leprosy ${ }^{11}$ to ensure that patients with primary dapsone-resistant leprosy would be recognized, and the data resulting from their participation in the trial would be analysed separately from those of the majority of the patients, whose $M$. leprae were expected to be fully susceptible to dapsone. The demonstration that more than one-third of the patients, presumed to have received no prior treatment, admitted to the trials in both treatment centres harboured dapsone-resistant $M$. leprae was unexpected.

One may question whether patients found to harbour dapsone-resistant $M$. leprae had not in fact received prior treatment. Because of its grave importance to a leprosy control programme, every effort must be made to identify primary resistance correctly. Some patients may relapse with secondary resistance but be considered instances of primary resistance because no evidence of previous treatment is discovered. When, however, there has been close contact with a patient known to have relapsed with secondary resistance ${ }^{8}$ or the patient's youth appears inconsistent with the long period of time required for diagnosis, treatment, response and relapse, ${ }^{12}$ primary resistance appears likely. Considerable effort was expended to ascertain that the patients admitted to the trials in Bamako and Chingleput had not been previously treated. The patients' urine, obtained as soon as admission to the trials was considered, contained no dapsone, 
and the patients steadfastly denied having received prior treatment. There was no record of their having been previously treated at either of the 2 centres, nor was the appearance of the patients' lesions suggestive of prior treatment followed by relapse. Moreover, in only 3 of 21 instances was there history of contact with a patient known to have relapsed with dapsone resistance. Finally, one might expect to be able to distinguish primary from secondary resistance on the basis of the patient's age. Because of the time required for emergence of secondary resistance-usually from 10 to 20 years, ${ }^{3}$ patients relapsing with secondary resistance to dapsone should have suffered from leprosy much longer and should therefore be older than multibacillary patients who have not been previously treated. In fact, as shown in Table 3, the age distribution of patients from whom dapsone-resistant $M$. leprae were isolated is not different from that of patients whose pretreatment isolates were susceptible to dapsone.

Surveys for primary resistance to dapsone have been carried out in Ethiopia, where a prevalence of 67 per 100 was found, ${ }^{4}$ and in the Philippines, where a much lower prevalence- 3.6 per 100 - was encountered. ${ }^{1}$

This present report, only the third published description of the results of a systematic study of the susceptibility to dapsone of $M$. leprae isolated from previously untreated patients, should be taken as cause for alarm and remedial action. The prevalence of primary resistance to dapsone encountered in Bamako and Chingleput signals the extensive transmission of dapsone-resistant $M$. leprae within these communities, and represents evidence that the epidemiologic background of leprosy in those communities has been transformed. Sources of new infections with $M$. leprae are no longer confined to previously untreated patients with drug-susceptible, multibacillary leprosy, but now include patients who have suffered relapse with secondary dapsone resistance. The more general ocurrence of leprosy resulting from infection with dapsone-resistant organisms portends additional difficulties for programmes of leprosy control, threatening as it does seriously to reduce the potency of one of the few effective drugs available.

On the other hand, the discovery of primary dapsone resistance of low degree does not imply that dapsone therapy will not benefit the patient. On the contrary, the patient may be expected to respond to treatment with dapsone in the full

Table 3. Age distribution of patients

\begin{tabular}{cccccc}
\hline & \multicolumn{2}{c}{ Bamako } & & \multicolumn{2}{c}{ Chingleput } \\
\cline { 2 - 3 } \cline { 5 - 6 } Age \\
\cline { 5 - 6 } (years) & Susceptible & Resistant & & Susceptible & Resistant \\
\hline \multirow{2}{*}{20} & 4 & 1 & & 2 & 5 \\
$20-39$ & 18 & 11 & & 30 & 13 \\
$>39$ & 2 & 1 & & 3 & 3 \\
\hline
\end{tabular}


dosage of $100 \mathrm{mg}$ per day. However, because resistance to dapsone appears to develop in stepwise fashion - that is, low-resistant $M$. leprae give rise to mutants of a higher degree of resistance, multibacillary patients are likely to relapse in time with fully-resistant $M$. leprae (a strain not inhibited by dapsone administered to the mice in a concentration of $0.01 \mathrm{~g}$ per $100 \mathrm{~g}$ diet) if dapsone is employed as monotherapy. ${ }^{6}$

Finally, the combined drug regimens recommended by the WHO Study Group on Chemotherapy of Leprosy for Control Programmes ${ }^{10}$ clearly were designed with the increasing frequency of dapsone resistance - both primary and secondary - in mind. The data presented in this report point to the urgency of adopting the Study Group regimens, and demonstrate the need to employ combined chemotherapy for treatment of paucibacillary as well as of multibacillary leprosy.

\section{References}

1 Guinto RS, Cellona RV, Fajardo TT, de la Cruz EC. Primary dapsone-resistant leprosy in Cebu, Philippines. Int J Lepr, 1981; 49: 427.

${ }^{2}$ Levy L, Peters JH. Susceptibility of Mycobacterium leprae to dapsone as a determinant of patient response to acedapsone. Antimicrob Ag Chemother, 1976; 9: 102.

${ }^{3}$ Pearson JMH. The problem of dapsone-resistant leprosy. Int J Lepr, 1981; 49: 417.

${ }^{4}$ Pearson JMH, Haile GS, Rees RJW. Primary dapsone-resistant leprosy. Lepr Rev, 1977; 48: 129.

${ }^{5}$ Pearson JMH, Waters MFR, Rees RJW. Sulphone resistance in leprosy. A review of one hundred proven clinical cases. Lancet, 1975; 2: 69.

${ }^{6}$ Pettit JHS, Rees RJW. Sulphone resistance in leprosy. An experimental and clinical study. Lancet, 1964; 2: 673.

7 Ridley DS, Jopling WH. Classification of leprosy according to immunity. A five-group system. Int J Lepr, 1966; 34: 255.

8 Russell DA, Worth RM, Jano B, Fasal P, Shepard CC. Acedapsone in the prevention of leprosy. Field trial in three high prevalence villages in Micronesia. Amer J Trop Med Hyg, 1979; 28: 559.

9 Shepard CC, Levy L, Fasal P. The sensitivity to dapsone (DDS) of Mycobacterium leprae from patients with and without previous treatment. Amer J Trop Med Hyg, 1969; 18: 258.

10 WHO Study Group. Chemotherapy of Leprosy for Control Programmes. Technical Report Series No. 675. WHO: Geneva, 1982.

11 Subcommittee on Clinical Trials. THELEP controlled clinical trials in lepromatous leprosy. Lepr Rev, 1983; 54: 167-176.

12 Utji R, Kosasih A, Santoso AUS. Dapsone-resistant leprosy in Jakarta: a preliminary report. Lepr Rev, 1983; 54: 193-195.

13 World Health Organization. A Guide to Leprosy Control. Geneva, 1980. 